\title{
Molecular Cloning of a Bacillus subtilis Gene Involved in Spore Outgrowth
}

\author{
By EUGENIO FERRARI, ${ }^{1}+$ FRANCESCO SCOFFONE, ${ }^{2}$ \\ GIOVANNI CIARROCCHI' AND ALESSANDRO GALIZZI ${ }^{*}$ * \\ 'Dipartimento di Genetica e Microbiologia 'A. Buzzati-Traverso', Università di Patia, Italy \\ 'Istituto di Genetica Biochimica ed Evoluzionistica del Consiglio Nazionale delle Ricerche, Pavia, \\ Italy
}

(Received 21 December 1984; revised 10 April 1985)

\begin{abstract}
A $\lambda$ Charon $4 \mathrm{~A}$ derivative carrying the outB gene of Bacillus subtilis has been identified by transformation of a $B$. subtilis mutant temperature-sensitive in spore outgrowth. The cloned region is a single $E c o \mathrm{RI}$ fragment $14 \mathrm{~kb}$ in legnth. In addition to out $B$, the cloned DNA includes at least part of the amyE and aroI loci.
\end{abstract}

\section{INTRODUCTION}

The process of bacterial endospore germination and outgrowth consists of an ordered sequence of events (Setlow, 1981; Albertini \& Galizzi, 1982). Mutants blocked at different stages of this sequence have been isolated in Bacillus subtilis and the mutations have been mapped on the chromosome (Piggot et al., 1981). The molecular cloning of some of the genes involved in the process may help in understanding the role of the different genes and should make it possible to study their expression and regulation at the molecular level. Moir (1983) isolated a $\lambda$ clone carrying the ger $A$ locus. Here we report the isolation of the out $B$ gene and its surrounding region from the $\lambda$ Charon 4A library of Ferrari et al. (1981) and physically characterize the $\lambda$ recombinant clone.

\section{METHODS}

Bacterial strains and media. The bacteria used are listed in Table 1. B. subtilis strains were cultured in nutrient broth (Difco) or the minimal medium of Spizizen (1958) for the preparation of competent cells. Minimal agar for selection of transformants was that of Davis \& Mingioli (1950). Testing for Amy ${ }^{+}$was done by plating on nutrient agar (Difco nutrient broth solidified with agar, $\left.10 \mathrm{~g} \mathrm{l}^{-1}\right)$ plates plus soluble starch $(1 \% \mathrm{w} / \mathrm{v})$. The plates were stained with a solution of $\mathrm{I}_{2}\left(\mathrm{I}_{0}^{\circ}, \mathrm{w} / \mathrm{v}\right)$ and $\mathrm{KI}(2 \%, \mathrm{w} / \mathrm{v})$ to identify Amy colonies, which were surrounded by a halo.

E. coli DP50 supF was used as a host for $\lambda$ Charon $4 \mathrm{~A}(\lambda \mathrm{Ch} 4 \mathrm{~A})$ and its recombinant derivatives. The nutrient medium used was modified LB comprising: Bacto-tryptone (Difco), $10 \mathrm{~g}$; yeast extract, $5 \mathrm{~g} ; \mathrm{NaCl}, 5 \mathrm{~g} ; \mathrm{MgCl}_{2}$, $2 \mathrm{~g}$ : diaminopimelic acid, $100 \mathrm{mg}$; thymidine, $50 \mathrm{mg}$; water, to 1 litre; $\mathrm{pH} 7 \cdot 1$. LB was solidified with $12 \mathrm{~g}$ agar or $10 \mathrm{~g}$ agarose $\mathrm{l}^{-1}$. For phage plating the top layer was either $4 \mathrm{~g}$ agar or $5 \mathrm{~g}$ agarose $\mathrm{l}^{-1}$. E. coli $\mathrm{HB} 10 \mathrm{l}$ was used for transformation and plasmid propagation in LB medium (Bacto-tryptone, $10 \mathrm{~g}$; yeast extract, $5 \mathrm{~g}$ : $\mathrm{NaCl}, 10 \mathrm{~g}$; water, to 1 litre; $\mathrm{pH} 7 \cdot 1$ ).

Phage and plasmid preparation. The library of B. subtilis DNA in $\lambda C h 4 A$ (Ferrari et al., 1981) was used. A plate lysate on agarose medium was prepared from each pool. The phage was harvested by centrifugation ( $75 \mathrm{~min}$ at 25000 r.p.m. in a Sorvall AH-627 swinging-bucket rotor), resuspended in $20 \mathrm{~mm}$-Tris $/ \mathrm{HCl}$ (pH 7.5) plus $25 \mathrm{~mm}$ EDTA and the DNA extracted with phenol. The DNA was used to transform competent cells of the mutant strain PB2427, which is temperature sensitive during spore outgrowth, selecting for the ability of the spores to yield colonies at $47^{\circ} \mathrm{C}\left(\mathrm{Ts}^{+}\right)$(Galizzi et al., 1973). Two hundred single plaques were separately collected from pool $\mathrm{G}$ (which consistently gave positive results), suspended in $50 \mu \mathrm{l} 10 \mathrm{~mm}$-Tris/ $\mathrm{HCl}$ (pH 7.5) plus $10 \mathrm{~mm}-\mathrm{MgSO}_{\downarrow}$ and

$\dagger$ Present address: Genentech Inc., South San Francisco, California, USA. 
Table 1. Strains of Bacillus subtilis and Escherichia coli

\begin{tabular}{|c|c|c|}
\hline Strain & Genotype & Source \\
\hline \multicolumn{3}{|l|}{ B. subtilis } \\
\hline PB19 & (prototroph) & SB19, Stanford Collection \\
\hline PB 1715 & metBS dal arol906 sac $A 32 I$ & $1 \mathrm{~A} 55, \mathrm{BGSC}$ \\
\hline PB2353 & thy $A$ thy $B$ arg tsc $G 47$ & Galizzi et al. (1976) \\
\hline PB2354 & thy $A$ thy $B$ arg tscH48 & Galizzi et al. (1976) \\
\hline PB2355 & $\operatorname{thy} A$ thy $B$ arg tsc $B 49$ & Galizzi et al. (1976) \\
\hline PB2427 & his $\mathrm{H} 2 \operatorname{trp} C 2$ outB8I & Albertini \& Galizzi (1975) \\
\hline PB2455 & arol906 dal out B8I & \\
\hline PB5009 & arol906 metB5 sac $A 321$ amy $E$ & IA 289, BGSC $^{*}$ \\
\hline \multicolumn{3}{|l|}{ E. coli } \\
\hline DP50sup $F$ & $\begin{array}{l}\mathrm{F}^{-} \text {tonA53 dapD8 lac Y1 supE } 44 \wedge(\text { gal-utrB }) 47 \text { glr } A 29 \\
\wedge(\text { thy } A 57) \text { hsd } 53\end{array}$ & Leder et al. (1977) \\
\hline HBIOl & $\begin{array}{l}\mathrm{F}^{-} \text {hsdS20 rec A } 13 \text { ara-14 proA2 lac Y1 galK2 rpsL20 } \\
x y l-5 \text { mtl-1 supE44 }\end{array}$ & Boyer \& Roulland-Dussoix (1969) \\
\hline
\end{tabular}

* BGSC, Bacillus Genetic Stock Center, Department of Microbiology, The Ohio State University, Columbus, Ohio 43210 , USA.

replated to give confluent lysis on small Petri dishes $(5 \mathrm{~cm}$ diameter) containing agarose medium. The phage was collected from each plate and DNA extracted by a fast procedure (Davis et al., 1980). Lysates were prepared from liquid cultures ( $1 \mathrm{l}$ ), the phage collected by polyethylene glycol precipitation and purified by $\mathrm{CsCl}$ density gradient centrifugation, and the DNA extracted with phenol.

Plasmids were prepared by the procedure of Birnboim \& Doly (1979). They were constructed by ligation of approximately equimolar amounts of gel-purified fragments. The extent of the $B$. subtilis DNA insert in each plasmid is shown in Fig. 4. Plasmid pO.EH contains a $5 \mathrm{~kb}$ fragment of $B$. subtilis DNA inserted into pBR325 (Bolivar, 1978), digested with EcoRI and HindIII. The B. subtilis fragment was obtained by digestion with EcoRI and HindIII of the entire $\lambda \mathrm{C} 4 \mathrm{BsG} 40$ DNA. The $5 \mathrm{~kb}$ fragment was purified by agarose gel electrophoresis before ligation. Transformants of $\mathrm{HB} 101$ resistant to $100 \mu \mathrm{g}$ ampicillin $\mathrm{ml}^{-1}$ were selected and screened for sensitivity to chloramphenicol $\left(25 \mu \mathrm{g} \mathrm{ml}^{-1}\right)$. Plasmid pO.SP is a derivative of pBR322. The B. subtilis DNA insert is of $7.7 \mathrm{~kb}$ and was obtained from $\lambda$ C4BsG 40 by digestion with EcoRI and Sall. The protruding ends were filled in with the Klenow fragment of DNA polymerase and the insert further digested with PstI. The PstI-Sall (blunt-ended) fragment was ligated to the pBR 322 vector digested with $E c o$ RI, whose ends were filled as above and then digested with PstI. Transformants of $\mathrm{HB} 101$ resistant to tetracycline $\left(12.5 \mu \mathrm{g} \mathrm{ml}^{-1}\right)$ were screened for sensitivity to ampicillin. To construct pO.P, a $3.6 \mathrm{~kb}$ fragment obtained by digestion with Pst $\mathrm{I}$ of the purified $14 \mathrm{~kb}$ insert of $\lambda$ C4BsG40 was ligated with PstI-digested and phosphatase-treated pBR322 DNA. The purified $14 \mathrm{~kb}$ insert of $\lambda$ C4BsG40 digested with $P s t I$ was also the source of the $2.8 \mathrm{~kb}$ fragment ligated to pBR322 (digested with PstI and $E(O \mathrm{RI})$ to give pO.PE. Plasmid pO.HH was constructed from pBR322. The $3.5 \mathrm{~kb}$ HindIII fragment was derived from $\lambda \mathrm{C} 4 \mathrm{BsG} 40$ and ligated to HindIII-digested and phosphatase-treated pBR322 DNA. Ampicillin-resistant transformants were screened for tetracycline sensitivity. The structure of each plasmid was confirmed by restriction analysis.

Transformation. The calcium shock procedure of Dagert \& Ehrlich (1979) was used for E. coli transformations. B. subtilis strains were transformed by the method of Anagnostopoulos \& Spizizen (1961).

Restriction enzyme mapping. DNA samples were digested with restriction endonucleases and fragments separated by electrophoresis in $0.7 \%$ or $1.2 \%(\mathrm{w} / \mathrm{v})$ agarose slab gels with Tris/acetate buffer (Cohen et al., 1973). For fragments of low molecular weight, $5 \%(\mathrm{w} / \mathrm{v})$ polyacrylamide gels were used. EcoRI-digested phage SPP 1 DNA was included in each gel as a size standard (Ratcliff et al., 1979). All enzymes were obtained from commercial suppliers and used under conditions recommended by the suppliers.

Isolation of a deletion mutant of phage $\lambda C 4 B s G 40$. A suspension of $\lambda \mathrm{C} 4 \mathrm{BsG} 40$ was prepared starting from a single plaque, suspended and plated to confluent lysis as described above. To $2 \mathrm{ml}$ of lysate $\left(2 \times 10^{10}\right.$ p.f.u. $\left.\mathrm{ml}^{-1}\right)$ was added 0.1 vol. $30 \%(\mathrm{w} / \mathrm{v})$ trisodium citrate monohydrate, and the mixture was incubated at $55^{\circ} \mathrm{C}$ for $1 \mathrm{~h}$, diluted and then plated (Parkinson \& Huskey, 1971). The phage was collected from confluent lysis plates and the cycle repeated. One hundred single plaques were collected, two successive single-plaque re-isolations were made from each and single plaques of each were used to produce confluent lysis on agarose plates from which DNA was extracted, digested with $E c o$ RI and analysed by agarose gel electrophoresis.

Electron microscopy of DNA molecules. Denaturation mix contained $5 \mu \mathrm{g}$ of each $\lambda$ phage DNA ml ${ }^{-1}$ and $0.1 \mathrm{M}^{-}$ $\mathrm{NaOH}, 0.02 \mathrm{M}$-EDTA. After incubation at room temperature for $10 \mathrm{~min}$, the samples were neutralized and reannealed as described by Davis et al. (1971). The DNA was spread from a hypophase containing $20 \%(\mathrm{v} / \mathrm{v})$ 


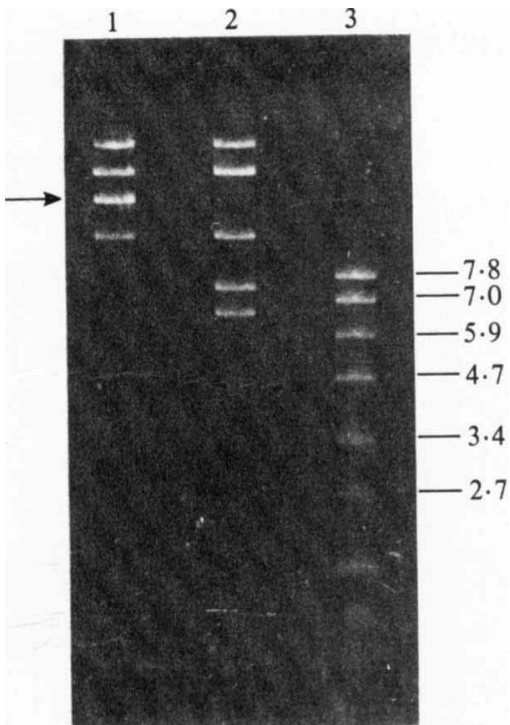

Fig. 1

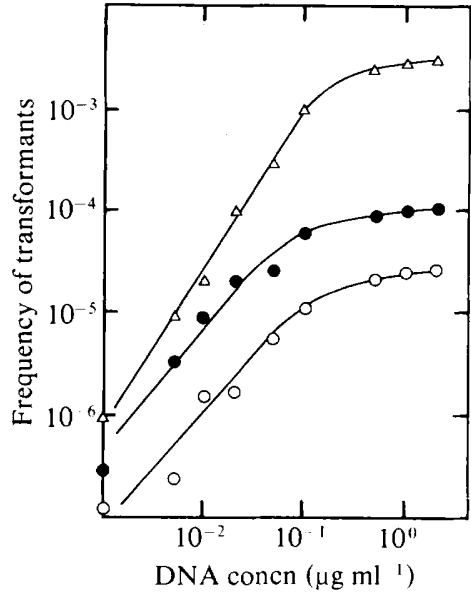

Fig. 2

Fig. 1. Agarose gel ( $0.7 \%$ ) electrophoresis of EcoRI-restricted DNA. Lane 1, DNA of $\lambda$ C4BsG40; lane 2. DNA of vector $\lambda \mathrm{Ch} 4 \mathrm{~A}$; lane 3, DNA of phage SPP 1 . The numbers indicate the sizes $(\mathrm{kb})$ of the phage SPPI fragments. The two internal EcoRI fragments of 6.5 and $7.5 \mathrm{~kb}$ present in $\lambda \mathrm{Ch} 4 \mathrm{~A}$ DNA are replaced by the $14 \mathrm{~kb}$ fragment of $\lambda \mathrm{C} 4 \mathrm{BsG} 40$ (arrow).

Fig. 2. Relationship between DNA concentration and frequency of transformation: Aro $^{+}$ transformants of strain PB1715, donor PB19 (O) and $\lambda \mathrm{C} 4 \mathrm{BsG} 40(O)$; $\mathrm{Ts}^{+}$transformants of strain $\mathrm{PB} 2427$, donor $\lambda \mathrm{C} 4 \mathrm{BsG} 40(\triangle)$. The values on the ordinate are the numbers of transformants per recipient cell.

formamide and a hyperphase containing $50 \%$ formamide and stained with uranyl acetate. Reference molecules were renatured $\lambda \mathrm{Ch} 4 \mathrm{~A}$ DNA and $\phi \mathrm{X} 174$ single-stranded circles. The molecules were visualized using a Philips EM301 electron microscope and photographed, and contour lengths were projected, traced and measured with an Apple II PC equipped with a digitizer.

\section{RESULTS AND DISCUSSION}

\section{Isolation of the out $B$ region}

Our purpose was to clone one of the genes involved in $B$. subtilis spore outgrowth. For this we used mutant PB2427 (outB81) which is temperature-sensitive (Ts) for outgrowth, as recipient in transformation with DNA from a $B$. subtilis library prepared in $\lambda \mathrm{Ch} 4 \mathrm{~A}$ (Ferrari et al., 1981). The library consisted of 19 pools each of about 100 individuals plaques. Each pool was plated to give confluent lysis on agarose plates, the phage collected and the DNA extracted and used to transform competent cells of strain PB2427, selecting for the ability of the spores to yield colonies at $47^{\circ} \mathrm{C}\left(\mathrm{Ts}^{+}\right)$(Galizzi et al., 1973). One pool transformed the recipient to $\mathrm{Ts}^{+}$. It was replated to give single plaques; plate lysates were prepared from 200 of these, and the DNA was extracted and used to transform PB2427. Five clones transformed to $\mathrm{Ts}^{+}$at a high frequency, all of which were identical in subsequent physical analysis. DNA from one clone ( $\lambda$ C4BsG40), when digested with $E c o$ RI, yielded a single $14 \mathrm{~kb}$ fragment of inserted chromosomal DNA (Fig. 1). DNA from the phage, either intact or digested with EcoRI, transformed an out $B$ recipient to $\mathrm{Ts}^{+}$. The relationship between DNA concentration and frequency of transformation by phage DNA is shown in Fig. 2. Of other markers close to out $B$, DNA from $\lambda \mathrm{C} 4 \mathrm{BsG} 40$ transformed aroI to prototrophy, $t s c B, t s c G$ and $t s c H$ (Galizzi et al., 1976) to $\mathrm{Ts}^{+}$and $a m y E$ to $\mathrm{Amy}^{+}$. The relationship between DNA concentration and frequency of $\mathrm{Aro}^{+}$transformation, for DNA extracted from $\lambda \mathrm{C} 4 \mathrm{BsG} 40$ and $B$. subtilis strain PB19, is shown in Fig. 2. $\lambda$ C4BsG40 DNA was about 10 -fold more efficient than chromosomal DNA at nonsaturating concentrations and the 
Table 2. Three-factor transformation crosses with markers of the out $B$ region

\begin{tabular}{|c|c|c|c|c|c|c|}
\hline \multirow[b]{2}{*}{ Cross } & \multirow[b]{2}{*}{ Donor } & \multirow[b]{2}{*}{ Recipient } & \multirow[b]{2}{*}{ Selection } & \multicolumn{2}{|c|}{ Recombinants } & \multirow{2}{*}{$\begin{array}{l}\text { Distances* } \\
\text { and } \\
\text { implied order }\end{array}$} \\
\hline & & & & Type & No. & \\
\hline 1 & $\begin{array}{l}\text { PB2427 } \\
\text { (out B81) }\end{array}$ & $\begin{array}{l}\text { PB5009 } \\
(\text { arol } 1906 \text { amy } E)\end{array}$ & $\mathrm{Aro}^{+}$ & $\begin{array}{l}\text { Out }^{+} \mathrm{Amy}^{+} \\
\mathrm{Out}^{+} \mathrm{Amy}^{-} \\
\mathrm{Out}^{-} \mathrm{Amy}^{+} \\
\text {Out }^{-} \mathrm{Amy}^{-}\end{array}$ & $\begin{array}{r}3 \\
122 \\
32 \\
218\end{array}$ & $\begin{array}{l}\text { arol906-outB8I: } 34 \\
\text { arol906-amyE: } 91\end{array}$ \\
\hline 2 & $\begin{array}{l}\text { PB5009 } \\
\text { (arol906 amy } E)\end{array}$ & $\begin{array}{l}\text { PB2427 } \\
\text { (outB81) }\end{array}$ & $\mathrm{Out}^{+}$ & $\begin{array}{l}\mathrm{Aro}^{+} \mathrm{Amy}^{+} \\
\text {Aro }^{+} \mathrm{Amy}^{-} \\
\text {Aro }^{-} \mathrm{Amy}^{+} \\
\text {Aro }^{-} \mathrm{Amy}^{-}\end{array}$ & $\begin{array}{l}74 \\
33 \\
95 \\
18\end{array}$ & $\begin{array}{l}\text { outB81-arol906: } 51 \\
\text { outB81-amy } E: 77 \\
\text { arol906-outB81 amyE }\end{array}$ \\
\hline 3 & $\begin{array}{l}\text { PB2355 } \\
(\text { tsc } B 49)\end{array}$ & $\begin{array}{l}\text { PB5009 } \\
(\text { aroI906 amyE) }\end{array}$ & $\mathrm{Aro}^{+}$ & $\begin{array}{l}\mathrm{Ts}^{+} \mathrm{Amy}^{+} \\
\mathrm{Ts}^{+} \mathrm{Amy}^{-} \\
\text {Ts Amy } \\
\text { Ts Amy }\end{array}$ & $\begin{array}{r}5 \\
25 \\
31 \\
49\end{array}$ & $\begin{array}{l}\text { arol906-tsc B49: } 28 \\
\text { arol906-amyE: } 67\end{array}$ \\
\hline 4 & $\begin{array}{l}\text { PB50009 } \\
\text { (arol906 amy E) }\end{array}$ & $\begin{array}{l}\mathrm{PB} 2355 \\
(t s c B 49)\end{array}$ & $\mathrm{Ts}^{+}$ & $\begin{array}{l}\text { Aro }^{+} \mathrm{Amy}^{+} \\
\text {Aro }^{+} \mathrm{Amy}^{-} \\
\text {Aro }^{-} \mathrm{Amy}^{+} \\
\text {Aro }^{-} \mathrm{Amy}^{-}\end{array}$ & $\begin{array}{r}8 \\
3 \\
30 \\
43\end{array}$ & $\begin{array}{l}\text { tscB49-arol906: } 13 \\
\text { tscB49-amyE: } 45\end{array}$ \\
\hline 5 & $\begin{array}{l}\mathrm{PB} 2353 \\
(t s c G 47)\end{array}$ & $\begin{array}{l}\text { PB5009 } \\
(\text { arol } 906 \text { amyE) }\end{array}$ & $\mathrm{Aro}^{+}$ & $\begin{array}{l}\mathrm{Ts}^{+} \mathrm{Amy}^{+} \\
\mathrm{Ts}^{+} \mathrm{Amy}^{-} \\
\text {Ts Amy } \\
\text { Ts Amy }\end{array}$ & $\begin{array}{r}4 \\
24 \\
30 \\
52\end{array}$ & $\begin{array}{l}\text { arol906-tscG47: } 26 \\
\text { aroly06-amy E: } 70\end{array}$ \\
\hline 6 & $\begin{array}{l}\text { PB5009 } \\
\text { (aro1906 amyE) }\end{array}$ & $\begin{array}{l}\mathrm{PB} 2353 \\
(t s c G 47)\end{array}$ & $\mathrm{Ts}^{+}$ & $\begin{array}{l}\mathrm{Aro}^{+} \mathrm{Amy}^{+} \\
\mathrm{Aro}^{+} \mathrm{Amy}^{-} \\
\mathrm{Aro}^{-} \mathrm{Amy}^{+} \\
\text {Aro }^{-} \mathrm{Amy}^{-}\end{array}$ & $\begin{array}{r}10 \\
5 \\
35 \\
43\end{array}$ & $\begin{array}{l}\operatorname{tsc} G 47-\operatorname{arol} 906: 16 \\
\operatorname{tsc} G 47-a m y E: 48\end{array}$ \\
\hline 7 & $\begin{array}{l}\text { PB2354 } \\
(t s c H 48)\end{array}$ & $\begin{array}{l}\text { PB5009 } \\
(\text { aroI } 906 \text { amyE) }\end{array}$ & Aro $^{+}$ & $\begin{array}{l}\mathrm{Ts}^{+} \mathrm{Amy}^{+} \\
\mathrm{Ts}^{+} \mathrm{Amy}^{-} \\
\mathrm{Ts} \mathrm{Amy}^{+} \\
\text {Ts Amy }\end{array}$ & $\begin{array}{r}2 \\
20 \\
41 \\
57\end{array}$ & $\begin{array}{l}\text { arol906-tsc H48: } 18 \\
\text { arol906-amy E: } 80\end{array}$ \\
\hline 8 & $\begin{array}{l}\text { PB5009 } \\
(\text { arol906 amyE) }\end{array}$ & $\begin{array}{l}\text { РB2354 } \\
\left(t s^{\prime} H 48\right)\end{array}$ & $\mathrm{Ts}^{+}$ & $\begin{array}{l}\mathrm{Aro}^{+} \mathrm{Amy}^{+} \\
\mathrm{Aro}^{+} \mathrm{Amy}^{-} \\
\mathrm{Aro}^{-} \mathrm{Amy}^{+} \\
\mathrm{Aro}^{-} \mathrm{Amy}^{-}\end{array}$ & $\begin{array}{r}5 \\
8 \\
20 \\
60\end{array}$ & $\begin{array}{l}\text { tsc } H 48 \text {-arol } 906: 14 \\
\text { tsc } H 48 \text {-amy: }: 27\end{array}$ \\
\hline
\end{tabular}

* The distances are expressed as 100 minus the percentage of cotransformation.

slopes of the dose-response curves are identical. The difference between the slopes of the doseresponse curves for $\mathrm{Aro}^{+}$and $\mathrm{Ts}^{+}$transformants, and the higher value of the plateau obtained in the latter case, are due to the fact that in transformation experiments in which selection is for $\mathrm{Ts}^{+}$, transformants are not directly scored after DNA uptake but only after sporulation.

\section{Genetic map of the outB region}

To obtain an indication of the position of the genes on the DNA carried by $\lambda$ C $4 \mathrm{BsG} 40$, we reexamined the genetic map of the region. The out $B$ marker was originally mapped by two-factor transduction crosses with phage PBS1, and $72 \%$ cotransduction with arol was observed (Albertini \& Galizzi, 1975). In two three-factor transformation crosses, the out $B$ locus was mapped with respect to aroI and amyE (Table 2, crosses 1 and 2) and the results are consistent with the order aroI-outB-amyE. Three additional mutations, $t s c B 49, t s c G 47$ and $t s c H 48$, which all result in temperature-sensitive vegetative growth, map in the same region (Galizzi et al., 1976). The results of reciprocal three-factor crosses, selecting separately for $\mathrm{Aro}^{+}$and $\mathrm{Ts}^{+}$

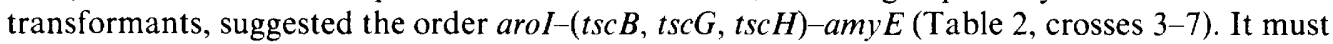
be noted that distances obtained in reciprocal crosses are not always congruent, thus the numbers should be taken as indicative. This is often the case with temperature-sensitive mutants, whose phenotype may be somewhat leaky. In particular we have encountered 
Table 3. Cotransformation of arol906 and outB81 with different DNA preparations

The recipient strain was PB2455 (arol906 outB81). $\lambda$ C4BsG40 (EcoRI) $=\lambda$ C4BsG40 digested with EcoRI prior to transformation. DNA concentrations were $0.05 \mu \mathrm{g} \mathrm{ml}^{-1}$.

\begin{tabular}{lcc}
\multicolumn{1}{c}{ Donor DNA } & $\begin{array}{c}\text { Frequency of } \\
\text { Aro }^{+} \text {transformants* }\end{array}$ & $\begin{array}{c}\text { Percentage of } \mathrm{Out}^{+} \\
\text {recombinants }\end{array}$ \\
PB19 & $5.8 \times 10^{-5}$ & $76(83 / 109)$ \\
$\lambda$ C4BsG40 & $3 \cdot 4 \times 10^{-+}$ & $77(57 / 74)$ \\
$\lambda$ C4BsG40 (EcoRI) & $9 \cdot 2 \times 10^{-5}$ & $83(152 / 184)$ \\
$*$ & Values are the numbers of transformants per recipient cell.
\end{tabular}

difficulties in measuring map distances in the out $B$ region, when selecting for $\mathrm{Ts}^{+}$. In the cross 1 of Table 2 the distance between aroI and $a m y E$ is higher than that reported in the literature (Nomura et al., 1978), and it is even higher in cross 2, in which PB2427 was the recipient. In the latter case the selection for transformants is applied only after sporulation and this may affect the final outcome of the cross. Due to difficulties in distinguishing among recombinant classes with the different temperature-sensitive phenotypes, we have not attempted to order out $B$ with respect to $t s c B, t s c G$ and $t s c H$.

From the results presented in the previous section, it appears that the $14 \mathrm{~kb}$ insert of $\lambda C 4 \mathrm{BsG} 40$ spans the region which includes the markers $a m y E$ and aroI. A measure of the linkage between aroI and out $B$ was obtained in transformation crosses using DNA from $B$. subtilis PB19 and DNA extracted from $\lambda$ C4BsG40 (Table 3). Cotransformation obtained with the cloned DNA was in good agreement with that obtained with chromosomal DNA. Digestion of $\lambda$ C4BsG40 DNA with EcoRI did not significantly affect cotransfer, although the frequency of transformation was lower (Table 3).

\section{Isolation of a deletion derivative of phage $\lambda C 4 B s G 40$}

Following treatment of $\lambda \mathrm{C} 4 \mathrm{BsG} 40$ with trisodium citrate a deletion mutant ( $\lambda$ C4BsG40 420 ) was isolated, the DNA of which was still able to transform $a m y E$, out $B, t s c B, t s c G$ and $t s c H$ markers, but not arol (data not shown).

\section{Physical analysis of the $\lambda C 4 B s G 40$ phage DNA}

DNA from $\lambda \mathrm{C} 4 \mathrm{BsG} 40, \lambda \mathrm{C} 4 \mathrm{BsG} 40 \Delta 20$ and $\lambda \mathrm{Ch} 4 \mathrm{~A}$ was digested with various restriction endonucleases and subjected to agarose or acrylamide gel electrophoresis. The $B$. subtilis DNA insert of $\lambda \mathrm{C} 4 \mathrm{BsG} 40$ has no restriction sites for $B a m H I, B g / \mathrm{II}$ or $S s t I$, but it has a single site for SalI, three sites for PstI and seven for HindIII. A restriction map of the cloned fragment is shown in Fig. 4. The deletion mutant $\lambda C 4 B s G 40 \Delta 20$, unable to transform aroI recipients to prototrophy, lacks about $4 \mathrm{~kb}$ of DNA. The DNA of this phage digested with EcoRI gave only two bands, one corresponding to the left arm of the vector DNA and one of high molecular weight, suggesting that the deletion abolished the second EcoRI site, connecting the $B$. subtilis insert to the right arm of $\lambda$. In particular, three HindIII fragments $(1480,1020$ and $680 \mathrm{bp})$ and the small $240 \mathrm{bp} H$ indIII-EcoRI fragment were missing. A new HindIII fragment of $4.4 \mathrm{~kb}$ was present at the junction of the insert to the vector right arm. The deletion abolished a Pst I site as well. From this we conclude that the deletion encompasses about $3 \mathrm{~kb}$ of the insert and about $1 \mathrm{~kb}$ of the right arm of the vector. Presumably it removes the entire bio-256 substitution present in $\lambda \mathrm{Ch} 4 \mathrm{~A}$ and stops at or near to the $N$ gene. A restriction map of the $\lambda \mathrm{C} 4 \mathrm{BsG} 40 \Delta 20$ is shown in Fig. 4.

The size of the insert in $\lambda \mathrm{C} 4 \mathrm{BsG} 40$ and the extent of the deletion in $\lambda \mathrm{C} 4 \mathrm{BsG} 40 \Delta 20$ were confirmed by heteroduplex analysis. Heteroduplexes were formed between the DNA of the vector and that of $\lambda \mathrm{C} 4 \mathrm{BsG} 40$ or $\lambda \mathrm{C} 4 \mathrm{BsG} 40 \Delta 20$ and between the DNA of $\lambda \mathrm{C} 4 \mathrm{BsG} 40$ and its deletion derivative (Fig. 3). Hybrid molecules between $\lambda \mathrm{Ch} 4 \mathrm{~A}$ and $\lambda \mathrm{C} 4 \mathrm{BsG} 40$ DNA gave a large region of single-stranded DNA (Fig. $3 a$ ). The lengths of the double-stranded segments correspond to the left $(19.9 \mathrm{~kb})$ and right $(11.0 \mathrm{~kb})$ arm of $\lambda \mathrm{Ch} 4 \mathrm{~A}$ respectively, while the length 

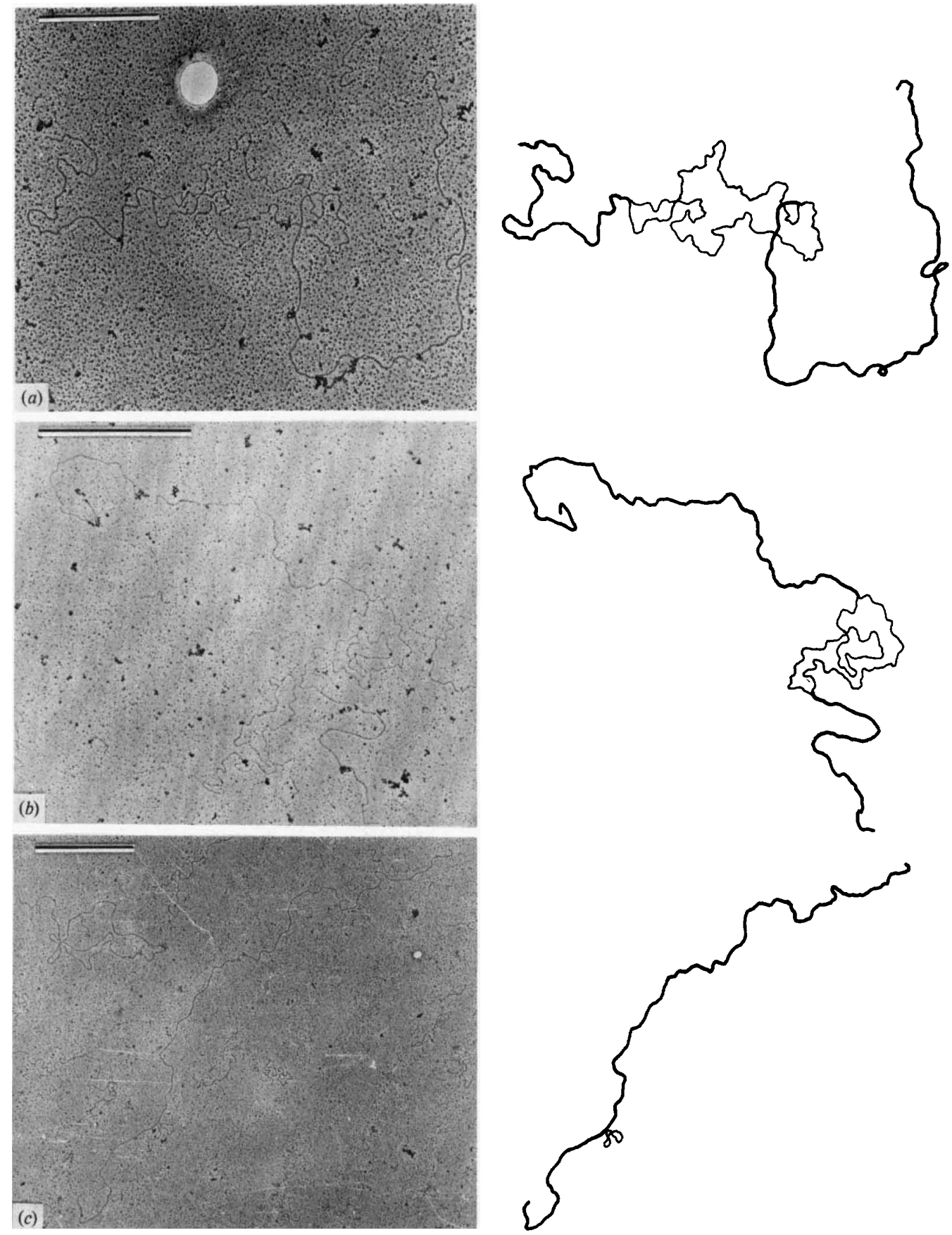

Fig. 3. Electron micrographs of heteroduplex molecules formed between $\lambda \mathrm{Ch} 4 \mathrm{~A}$ and recombinant derivatives. (a) $\lambda \mathrm{Ch} 4 \mathrm{~A}$ and $\lambda \mathrm{C} 4 \mathrm{BsG} 40 ;$ (b) $\lambda \mathrm{Ch} 4 \mathrm{~A}$ and $\lambda \mathrm{C} 4 \mathrm{BsG} 40 \Lambda 20 ;$ (c) $\lambda \mathrm{C} 4 \mathrm{BsG} 40$ and $\lambda C 4 B s G 40 \wedge 20$. Drawings of the heteroduplexes are shown on the right. Bars, $5 \mathrm{~kb}$. 
$(t s c B, t s c G, t s c H)$

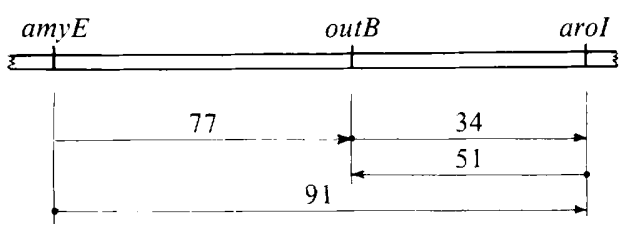

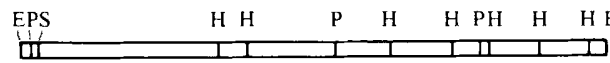
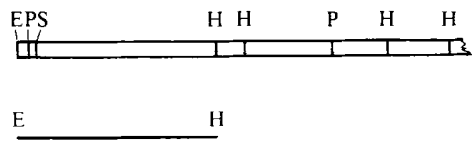

S

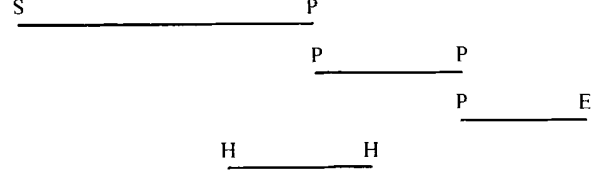
$\mathrm{H}$

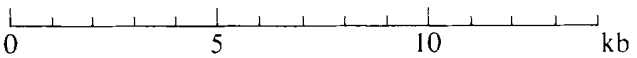

$\lambda \mathrm{C} 4 \mathrm{BsG} 40$

$\lambda \mathrm{C} 4 \mathrm{BsG} 40 \Delta 20$

pO.EH

pO.SP

pO.P

pO.PE

pO.HH

\section{Marker rescue \\ amyE outB $t s c B, G, H$ aroI}

Fig. 4. Genetic and restriction map of the region surrounding the out $B$ gene. The genetic map is based on reciprocal three-factor transformation crosses (Table 2). The map distances are expressed as 100 minus the percentage of cotransformation. The head of the arrow points to the donor selected marker. The lower part of the figure is a restriction map of $\lambda \mathrm{C} 4 \mathrm{BsG} 40$ and of its deletion derivative $\lambda C B s G 40 \triangle 20$, and the extent of the fragments subcloned into plasmids. The results of the marker rescue experiments are summarized to the right of each clone. E, EcoRI; H, HindIII; P, PstI; S, Sall.

of the two single strands of each loop is about $14 \mathrm{~kb}$. Thus we cannot distinguish between the loop of $\lambda \mathrm{Ch} 4 \mathrm{~A}$ and the one contributed by $\lambda \mathrm{C} 4 \mathrm{BsG} 40$. In the $\lambda \mathrm{Ch} 4 \mathrm{~A} / \lambda \mathrm{C} 4 \mathrm{BsG} 40 \Delta 20$ heteroduplex (Fig. $3 b$ ) one double-stranded region is the same length as the left arm, while the other is only $10 \mathrm{~kb}$, instead of $10.9 \mathrm{~kb}$ long. The individual single-stranded loops have sizes of $15.9 \mathrm{~kb}(\lambda \mathrm{Ch} 4 \mathrm{~A})$ and $11.3 \mathrm{~kb}(\lambda \mathrm{C} 4 \mathrm{BsG} 40 \Delta 20)$. As expected, in $\lambda \mathrm{C} 4 \mathrm{BsG} 40 / \lambda \mathrm{C} 4 \mathrm{Bs} 40 \Lambda 20$ heteroduplexes, the deletion resulted in a loop about $4 \mathrm{~kb}$ in length, positioned $30 \mathrm{~kb}$ from one end and $9.6 \mathrm{~kb}$ from the other (Fig. $3 c$ ).

\section{Comparison between the genetic and the physical map}

The deletion of about $3 \mathrm{~kb}$ from the right of the insert in $\lambda \mathrm{C} 4 \mathrm{BsG} 40 \triangle 20$ completely abolished the ability to transform for the aroI marker, which allowed orientation of the genetic map with the restriction map. Additional data were obtained by subcloning fragments of the insert into suitable plasmids, pBR322 and pBR325 (Fig. 4). Plasmid pO.PE, carrying the Pst I-EcoRI fragment of $2.8 \mathrm{~kb}$ from the right end of the insert, transformed arol 906 to prototrophy, but failed to transform outB, $t s c B, t s c G, t s c H$ and amyE. Plasmid pO.P transformed to $\mathrm{Ts}^{+}$strains with the outB81 mutation, whereas pO.HH did not. Therefore outB81 must lie between the HindIII site at coordinate 9 , and the PstI site at coordinate 11 of our insert. Obviously the ability to transform to wild-type does not guarantee that the entire gene is present on a specific DNA fragment, since only the portion of the gene which includes the part equivalent to the site of the mutation is required. Plasmid pO.P also transformed $t s c B 49$, tscG 47 and $t s c H 48$ recipients to $\mathrm{Ts}^{+}$. It may be that the four mutations are all in the same gene, but this seems unlikely on phenotypic grounds, since only the outB81 mutation affects outgrowth specifically. Perhaps the other three mutations, which affect vegetative growth, represent collectively a separate gene. $t s c G$ and $t s c H$ belong to the same physiological class and $t s c B$ and $t s c G$ are very closely linked, with a recombination index of 0.02 (Galizzi et al., 1976). According to the transformation data 
with subcloned fragments (Fig. 4), the $a m y E$ gene resides in the left part of the $\lambda C 4 B s G 40$ insert. Nucleotide sequence analysis has revealed that the clone carries only the $3^{\prime}$ part of the amyE gene (Yang et al., 1983).

In conclusion, we have cloned a region of the $B$. subtilis chromosome which includes the out $B$ gene, whose function is specifically required during spore outgrowth. This should enable us to study the role of the gene at the molecular level.

Thanks are due to J. Hoch for suggestions and encouragement, to $M$. Yang for help in the subcloning of fragments, to V. Sgaramella for the use of the electron microscope and to D. Formenti for the Apple II PC equipped with a digitizer.

The work was partially supported by Consiglio Nazionale delle Ricerche (Rome) grants CT 82.00168.04, 83.01990.04 and Progetto Finalizzato Oncologia.

\section{REFERENCES}

Albertini, A. M. \& Galizzi, A. (1975). Mutant of Bacillus subtilis with a temperature-sensitive lesion in ribonucleic acid synthesis during germination. Journal of Bacteriology 124, 14-25.

Albertini, A. M. \& Galizzi, A. (1982). Pattern of RNA transcription during Bacillus subtilis spore outgrowth. Journal of General Microbiology 128, 247 253.

Anagnostopoulos, C. \& Spizizen, J. (1961). Requirements for transformation in Bacillus subtilis. Journal of Bacteriology 81, 741-746.

Birnboim, H. C. \& Doly, J. (1979). A rapid alkaline extraction procedure for screening recombinant plasmid DNA. Nucleic Acids Research 7, 15131523.

Bolivar, F. (1978). Construction and characterization of new cloning vehicles. III. Derivatives of plasmid pBR322 carrying unique EcoRI sites for selection of EcoRI generated recombinant DNA molecules. Gene 4, 121-136.

Boyer, H. W. \& Roulland-Dussolx, D. (1969). A complementation analysis of the restriction and modification of DNA in Escherichia coli. Journal of Molecular Biology 41, 459-472.

Cohen, S. N., Chang, A. C. Y., Boyer, H. W. \& Helling, R. B. (1973). Construction of biologically functional bacterial plasmids in vitro. Proceedings of the National Academy of Sciences of the United States of America 70, 3240-3244.

Dagert, M. \& Ehrlich, S. D. (1979). Prolonged incubation in calcium chloride improves the competence of Escherichia coli cells. Gene 6, 23-28.

Davis, M. \& Mingioli, E. S. (1950). Mutants of Escherichia coli requiring methionine or vitamin B12. Journal of Bacteriology 60, 17-28.

Davis, R. W., Simon, M. \& Davidson, N. (1971). Electron microscope heteroduplex methods for mapping regions of base sequence homology in nucleic acids. Methods of Enzymology 21, 413-428.

Davis, R. W., Botstein, D. \& Roth, J. H. (1980). Rapid $\lambda$ DNA isolation. In Advanced Bacterial Genetics: a Manual for Genetic Engineering, pp. 109 111. New York: Cold Spring Harbor Laboratory.

Ferrari, E., Henner, D. \& Hoch, J. A. (1981). Isolation of Bacillus subtilis genes from a Charon 4A library. Journal of Bacteriology 146, 430-432.

Galizzi, A., Gorrini, F., Rollier, A. \& Polsinelli, M. (1973). Mutants of Bacillus subtilis temperature sensitive in the outgrowth phase of spore germination. Journal of Bacteriology 113, 1482-1490.

Galizzi, A., Siccardi, A. G., Mazza, G., Canosi, U. \& Polsinelli, M. (1976). A recombination test to classify mutants of Bacillus subtilis of identical phenotype. Genetical Research 27, 47-58.

Leder, P., Tiemeier, D. \& Enquist, L. (1977). EK2 derivatives of bacteriophage lambda useful in the cloning of DNA from higher organisms: the $\lambda \mathrm{gt} W E S$ system. Science 196, 175-177.

MOIR, A. (1983). The isolation of $\lambda$ transducing phages carrying the cit $G$ and ger $A$ genes of Bacillus subtilis. Journal of General Microbiology 129, 303-310.

Nomura, S., Yamane, K., Sasaki, T., Yamasaki, M., TAMura, G. \& Maruo, B. (1978). Tunicamycinresistant mutants and chromosomal locations of mutational sites in Bacillus subtilis. Journal of Bacteriology 136, 818-821.

Parkinson, J. S. \& Huskey, R. J. (1971). Deletion mutants of bacteriophage lambda. Isolation and initial characterization. Journal of Molecular Biology 56, 369-384.

Piggot, P. J., MoIr, A. \& SMith, D. A. (1981). Advances in the genetics of Bacillus subtilis differentiation. In Sporulation and Germination, pp. 29-39. Edited by H. S. Levinson, A. L. Sonenshein \& D. J. Tipper. Washington, DC: American Society for Microbiology.

RatClifF, S. W., Luh, J., Ganesan, A. T., Behrens, B., Thompson, R., Montenegro, M. A., Morelli, G. \& Trautner, T. A. (1979). The genome of Bacillus subtilis phage SPPI: the arrangement of restriction endonuclease generated fragments. Molecular and General Genetics 168, 165-172.

SETLOW, P. (1981). Biochemistry of bacterial forespore development and spore germination. In Sporulation and Germination, pp. 13-28. Edited by H. S. Levinson, A. L. Sonenshein \& D. J. Tipper. Washington, DC: American Society for Microbiology.

Spizizen, J. (1958). Transformation of biochemically deficient strains of Bacillus subtilis by deoxyribonucleate. Proceedings of the National Academy of Sciences of the United States of America 44, 1072-1078.

YanG, M., Galizzi, A. \& Henner, D. (1983). Nucleotide sequence of the amylase gene from Bacillus subtilis. Nucleic Acids Research 11. 237-249. 